\title{
Prognostic Value of Preoperative Neutrophil-lymphocyte/ Platelet-lymphocyte Ratio in Patients with Stage II-III Rectal Cancer Who Underwent Curative Resection
}

\author{
Küratif Rezeksiyon Uygulanan Evre II-III Rektum Kanserli Hastalarda Preoperatif \\ Nötrofil-lenfosit/Trombosit-lenfosit Oranının Prognostik Değeri
}

\begin{abstract}
(D) Özlem Mermut ${ }^{1}$, (1) Berrin İnanç1, (1) Nevra Dursun², (1) Didem Can Trabulus³, (1) Aytül Hande Yardımcı4, (D) Esra Arslan 5
\end{abstract}

1University Health Sciences Turkey, İstanbul Training and Research Hospital, Clinic of Radiation Oncology, i̇stanbul, Turkey 2University Health Sciences Turkey, İstanbul Training and Research Hospital, Clinic of Pathology, İstanbul, Turkey ${ }^{3}$ University Health Sciences Turkey, İstanbul Training and Research Hospital, Clinic of General Surgery, İstanbul, Turkey 4University Health Sciences Turkey, İstanbul Training and Research Hospital, Clinic of Radiology, İstanbul, Turkey

5 University Health Sciences Turkey, İstanbul Training and Research Hospital, Clinic of Nuclear Medicine, İstanbul, Turkey

\begin{abstract}
Introduction: This study aimed to evaluate the prognostic value and survival effects of the neutrophil-lymphocyte/ platelet-lymphocyte ratio (NLR/PLR) in the preoperative peripheral blood count of patients who underwent curative resection due to stage II-III rectal cancer.

Methods: Between 2011 and 2017, a total of 156 patients with stage II-III rectal cancer who underwent curative resection were evaluated. Before the curative resection, complete blood counts were obtained within 3 days. The last follow-up was in December 2018. NLR and PLR were calculated by dividing the absolute neutrophil or platelet count by the absolute lymphocyte count, respectively.

Results: Postoperatively, adenocarcinoma histology $(p=0.025)$, R1 resection $(p<0.001)$, T4 stage $(p=0.001)$, N stage positivity $(p=0.003)$, tumor-node-metastasis (TNM) stage III disease $(p=0.002)$, presence of lenfovascular invasion $(p<0.001)$, presence of perineural invasion $(p<0.001)$, preoperative NLR $\geq 3.6(p<0.001)$ and PLR $\geq 192(p<0.001)$ were identified in the rectal cancer patients as factors that influence survival in univariate analysis. In our study, R1 resection [hazard ratio (HR): 0.341 ; $95 \%$ confidence interval $(\mathrm{Cl})$ : $0.157-0.740$; $\mathrm{p}=0.007]$; T4 stage (HR: $0.261 ; 95 \% \mathrm{Cl}: 0.129-0.527 ; \mathrm{p}<0.001)$, N0 stage vs N1 positivity (HR: $0.071 ; 95 \% \mathrm{Cl}: 0.010-0.525$; $p=0.010)$, N0 stage vs N2 positivity (HR: $0.068 ; 95 \% \mathrm{Cl}: 0.008-$ $0.565 ; p=0.013$ ), presence of metastases (HR: $0.130 ; 95 \% \mathrm{Cl}$ : $0.054-0.309, p<0.001)$, TNM stage III (HR: $0.261 ; 95 \% \mathrm{Cl}: 0.129-$ $0.527, \mathrm{p}<0.001$ ) and preoperative NLR $\geq 3.6$ (HR: $0.378 ; 95 \% \mathrm{Cl}$ : 0.154-0.930, $p=0.034$ ) were identified as independent factors affecting survival in multivariate analysis.
\end{abstract}

\section{öZ}

Amaç: Bu çalıșmada evre II-III rektum kanseri ile küratif rezeksiyon uygulanan hastalarda preoperatif periferik kan sayımlarında nötrofil-lenfosit/trombosit-lenfosit oranının (NLO/PLO) prognostik değeri ve sağkalım etkilerinin değerlendirilmesi amaçlanmıștır.

Yöntemler: 2011-2017 yılları arasında küratif rezeksiyon uygulanan evre II-III rektum kanserli 156 hasta değerlendirildi. Küratif rezeksiyondan önce, tam kan sayımı 3 gün içinde elde edildi. Son takip Aralık 2018 oldu. NLO ve PLO, mutlak nötrofil veya trombosit sayısının mutlak lenfosit sayısına bölünmesiyle hesaplandı.

Bulgular: Postoperatif olarak, rektum kanseri hastalarında adenokarsinom histolojisi ( $p=0,025), R 1$ rezeksiyonu $(p<0,001)$, T4 evre $(p=0,001)$, N evre pozitifliği $(p=0,003)$, tümör-nodmetastaz (TNM) evre 3 hastalığı $(p=0,002)$, lenfovasküler istila varlığı $(p<0,001)$, perinöral invazyon varlığı $(p<0,001)$, preoperatif $\mathrm{NLO} \geq 3,6 \quad(p<0,001)$ ve PLO $\geq 192 \quad(p<0,001)$ univariate analizde sağkalımı etkileyen faktörler olarak tanımlanmıştır. Çalıșmamızda R1 rezeksiyonu [tehlike oranı (HR): 0,341; \%95 güven aralığı (GA): 0,157-0,740; $p=0,007]$; T4 evresi (HR: 0,261; \%95 GA: 0,129-0,527; $p<0,001)$, N0'a karş। N1 pozitifliği (HR: 0,071; \%95 GA: 0,010-0,525; $p=0,010$ ), N0'a karșı N2 pozitifliği (HR: 0,068; \%95 Cl: 0,008-0,565; $p=0,013)$, metastaz varlığı (HR: 0,130; \%95 GA: 0,054-0,309, $p<0,001$ ), TNM evre III (HR: 0,261; \%95 GA: 0,129-0,527, $p<0,001$ ) ve preoperatif NLR $\geq 3,6$ (HR: 0,378; \%95 GA: 0,154-0,930, $p=0,034$ ) multivariate analizde sağkalımı etkileyen bağımsız faktörler olarak tanımlandı.

Cite this article as/Atıf: Mermut Ö, İnanç B, Dursun N, Trabulus DC, Yardımcı AH, Arslan E. Prognostic Value of Preoperative Neutrophil-lymphocyte/Platelet-lymphocyte Ratio in Patients with Stage II-III Rectal Cancer Who Underwent Curative Resection. İstanbul Med J 2020; 21(5): 384-90.

(C) Copyright 2020 by the University of Health Sciences Turkey, Istanbul Training and Research Hospital/istanbul Medical Journal published by Galenos Publishing House.

(C) Telif Hakkı 2020 Sağıı Bilimleri Üniversitesi Istanbul Ĕgitim ve Araştırma Hastanesi/Istanbul Tıp Dergisi, Galenos Yayınevi tarafından basılmıștır. 
Conclusion: In our study, due to the low cost, it extensive use, and association with overall survival, NLR was found to be a better prognostic marker. Besides, R1 resection, T4 stage, lymph node positivity, presence of metastases, TNM stage III were found to be prognostic factors that negatively affect overall survival. NLR is a biomarker that is thought to be an indicator of the systemic inflammatory response and can be easily obtained as a prognostic biomarker candidate.

Keywords: Stage II, III rectum cancer, neutrophil-lymphocyte, platelet-lymphocyte ratio, prognosis
Sonuç: Çalışmamızda, düşük maliyetli, yaygın olarak kullanılan, genel sağkalım ile ilișkili, NLO'nun daha iyi bir prognostik belirteç olduğu bulunmuștur. Ayrıca R1 rezeksiyon, T4 evresi, lenf nodu pozitifliği, metastaz varlığı, TNM evre III genel sağkalımı olumsuz etkileyen prognostik faktörler olarak bulundu. NLO sistemik enflamatuvar yanıtın bir göstergesi olduğu düşünülen ve prognostik biyobelirteç adayı olarak kolayca elde edilebilen bir biyobelirteçtir.

Anahtar Kelimeler: Evre II, III rektum kanseri, nötrofil-lenfosit, trombosit-lenfosit oranı, prognoz

\section{Introduction}

Colorectal cancers is the third most common cancer in the world. Surgery is chosen for the treatment of non-metastatic diseases and postoperative treatment is usually managed according to the tumor-node-metastasis (TNM) staging system (1). Cancer-related inflammation, tumour and host- derived cytokines, immune cells and small inflammatory protein agents cover leukocytes, neutrophils, lymphocytes and platelets and is determined by the levels of acute-phase proteins $(2,3)$. Lymphocytes play a crucial role in cytotoxic cell death and cytokine production, which prevents proliferation and metastasis of malignant cells (4). Elevated neutrophil count increases tumour growth and metastasis by remodelling the extracellular matrix, thereby releasing reactive oxygen species and suppressing lymphocyte activity (5). Also, the presence of tumour cells affects platelets and causes cancer-related thrombosis (6). Platelets excrete growth factors that support tumour growth, angiogenesis and metastasis (7). Increased NLR seems to be related with a poor prognosis in different cancers (8-11). We know that patients at an equal stage can have separate clinical features and outcomes. In clinical practice, simple methods such as NLR added to TNM staging can help with this situation to create an individualised treatment strategy.

We aimed to evaluate the prognostic value and survival effects of the neutrophil-lymphocyte ratio (NLR)/platelet-lymphocyte ratio (PLR) in the preoperative peripheral blood counts of patients who underwent curative resection with stage II-III rectal cancer.

\section{Methods}

A total of 156 patients with stage II-III rectal cancer who underwent curative resection between 2011 and 2017 were evaluated. The last follow-up was in December 2018. Before the curative resection, complete blood count were obtained within 3 days. Complete blood count was performed with XN-900 Haematology analyser (Symex, Japan). The normal reference range for lymphocytes was $1.18-3.57 \times 10^{9}$ / $\mathrm{L}$, for neutrophils $1.56-6.13 \times 10^{9} / \mathrm{L}$ and platelets for $142-424 \times 10^{9} / \mathrm{L}$. We determined the cut-off with the receiver operating characteristic curve for NLR 3.6 [area under the curve (AUC): 0.791; 95\% confidence interval $(\mathrm{Cl})$ : 0.711-0.872; $\mathrm{p}<0.001$ ] and PLR 192 (AUC: 0.784; 95\% Cl: 0.704$0.864 ; p<0.001)$. Colonoscopy and biopsy were performed to diagnose all the patients preoperatively. For staging, a computed tomography (CT) scan of the thorax and abdomen or an 18-florodeoksiglukoz positron emission tomography $\mathrm{CT}$ was performed. Pelvic magnetic resonance imaging for local disease staging was performed. R0 resection has no postoperative residual tumour and $\mathrm{R} 1$ resection has been accepted as the presence of the microscopic residual tumour. In 25-28 fraction, daily dose of 180-200 cGy, 5,000-5,040 cGy, 5-6 weeks, radiotherapy (RT) was applied. From the first day of RT, continuous bolus infusion 5-FU $\left(225 \mathrm{mg} / \mathrm{m}^{2}\right)$ or 5 -FU $\left(425 \mathrm{mg} / \mathrm{m}^{2}\right)+$ calcium leucovorin $\left(20 \mathrm{mg} / \mathrm{m}^{2}\right)$ was given throughout RT. T-test or Mann-Whitney $U$ test were used for noncategorical variables; chi-square and Fisher's exact tests were used for categorical variables. Categorical variables were presented as absolute numbers and percentage values for the NLR and PLR. Prognostic values of each variable were evaluated with univariate and multivariate Cox proportional regression analyses. Overall survival (OS) was calculated and compared using the Kaplan-Meier method and Log-rank test. Inclusion criteria of patients: (1) primary rectal cancer diagnosed in the postoperative stage II,III; (2) patients undergoing radical surgery without neoadjuvant therapy; (3) those with complete blood count and followup data. Exclusion criteria were as follows: (1) the presence of infection or haematological disease; (2) to apply neoadjuvant radiochemotherapy first; (3) to have emergency surgery due to bowel obstruction; (4) synchronous/metacron other than cancers; (5) use of anti-inflammatory or immunosuppressive drugs; (6) except neuroendocrine tumours.

\section{Statistical Analysis}

Statistical analysis was performed using SPSS software version 22.0 (SPSS, Chicago, IL, USA). A p-value of less than 0.05 from a two-tailed test was considered statistically significant. This study was approved by University Health Sciences Turkey, İstanbul Training and Research Hospital's Ethics Committee (decision no: 2244/ date: 27.04.2020). Due to the retrospective design of the study, informed consent was not obtained from the patients.

\section{Results}

The median age was 61 (range: 22-83). The median tumour diameter was $5.06 \pm 1.85 \mathrm{~cm}$ (range: $2-12.5$ ). Of our patients, 71 (46\%) were females and 85 (54\%) were males. Male/female ratio was 1.1/.ost of our patients were located in the upper rectum (n 95; 61\%). Thirty-one (20\% in the middle rectum and $30(19 \%)$ in the lower rectum. One hundred and twenty-six (81\%) patients were operated by low anterior resection and 30 (19\%) by abdominoperineal resection. One hundred and nineteen (76\%) patients were adenocancers, 20 (13\%) patients were mucinous cancers, 16 (11\%) patients were in mixed type (adenocancer + mucinous) histology. There were 7 (5\%) patients who did not apply RT and 4 (3\%) patients who did not use chemotherapy. Liver metastasis was detected in 17 (11\%) 
patients, lung metastasis in 17 (11\%) patients, local recurrence in 14 (9\%) patients and peritoneal metastasis in 14 (9\%) patients. The number of patients with fewer than 12 lymph nodes removed during surgery was 28 (18\%). Since carcinoembryonic antigen was not assessed in all the patients (only 94 patients were evaluated), we did not evaluate the survival with tumour markers in our study. The general characteristics of the patients are shown in Table 1.

NLR $\geq 3.6$ values were in present 68 (44\%) patients and PLR $\geq 192$ values

Table 1. General demographics of patients (lenfovascular invasion, perineural invasion, neutrophil-lymphocyte ratio, platelet-lymphocyte ratio)

\begin{tabular}{|l|l|l|}
\hline & Number of patients & $\%$ \\
\hline Age (median \pm SD) & $61 \pm 12.29$ & - \\
\hline Gender & & 45 \\
\hline Female & 71 & 55 \\
\hline Male & 85 & \\
\hline
\end{tabular}

\section{Histology}

Adenocancer

Others

119

37

80

76

Present

PNI

Absent

Present

95

61

61

\section{Surgical resection}

\section{R1}

R0

\section{3}

133

\begin{tabular}{|l|l|}
\hline 13 & 8 \\
\hline 110 & 71 \\
\hline 33 & 21 \\
\hline
\end{tabular}

\section{$\mathrm{N}$ stage}

0

1

2

\section{TNM Stages}

II

III

Metastases

Absent

Present

66

57

33

76

24

\section{1}

49

61

39

64

63

93

40

60

NLR

$N L R<3.6$

$N L R \geq 3.6$

94

62

60

62

40

PLR

PLR $<192$

PLR $\geq 192$

88
68

56

44

84

72

54

46

NLR: Neutrophil-lymphocyte ratio, PLR: platelet-lymphocyte ratio, LVI: lenfovascular invasion, PNI: perineural invasion, SD: standard deviation, TNM: tumor-node-metastasis in 72 (46\%) patients. According to NLR $<3.6$ vs NLR $\geq 3.6$ and PLR $<192$ VS $P L R \geq 192$, Iymph node involvement, TNM stage III, lenfovascular invasion (LVI) and perineural invasion (PNI) were statistically significant. The demographic comparisons of the patients according to NLR and PLR values are shown in Table 2.

Postoperatively, adenocarcinoma histology $(p=0.025)$, R1 resection $(p<0.001)$, T4 stage $(p=0.001)$, N stage positivity $(p=0.003)$, TNM stage III disease $(p=0.002)$, presence of LVI $(p<0.001)$, presence of PNI $(p<0.001)$, preoperative $N L R \geq 3.6(p<0.001)$ and $P L R \geq 192(p<0.001)$ were identified as factors in rectal cancer patients that influence survival in univariate analysis.

In our study, R1 resection [hazard ratio (HR): $0.341 ; 95 \% \mathrm{Cl}: 0.157-0.740$; $\mathrm{p}=0.007)]$; T4 stage (HR: 0.261; 95\% Cl: 0.129-0.527; $\mathrm{p}<0.001)$, N0 stage vs N1 positivity (HR: $0.071 ; 95 \% \mathrm{Cl}: 0.010-0.525 ; \mathrm{p}=0.010$ ), N0 stage vs N2 positivity (HR: $0.068 ; 95 \% \mathrm{Cl}: 0.008-0.565 ; p=0.013$ ), presence of metastases (HR: $0.130 ; 95 \% \mathrm{Cl}: 0.05-0.309, \mathrm{p}<0.001)$, TNM stage III (HR: 0.261; 95\% Cl: $0.129-0.527, \mathrm{p}<0.001$ ) and preoperative NLR $\geq 3.6$ (HR: 0.378; $95 \% \mathrm{Cl}: 0.154-0.930, p=0.034)$ were identified as independent factors affecting survival in multivariate analysis (Table 3).

The 5 -year OS was $70 \%$ for stage II and $46 \%$ for stage III (Figure 1).

\section{Discussion}

There are many factors that impact the prognosis of colorectal cancer, due to its tumour heterogeneity (12). Colorectal cancer (CRC) risk increases with age (13). In this study, the median age was found as 61 years. Like in our study, the distribution of gender was nearly equal as in other studies. There was a mild male dominance $(14,15)$. Adenocarcinoma is the most familiar histological subtype of CRC, while the mucinous and signet ring cell subtypes are more common in younger patients (16).

In rectal cancer, $\mathrm{R} 1$ resection is an independent risk factor that negatively affects the OS. Neoadjuvant RT decreases R1 resection and we have to avoid R1 resection $(17,18)$. We also found that $\mathrm{R} 1$ resection was an independent risk factor that shortens the OS.

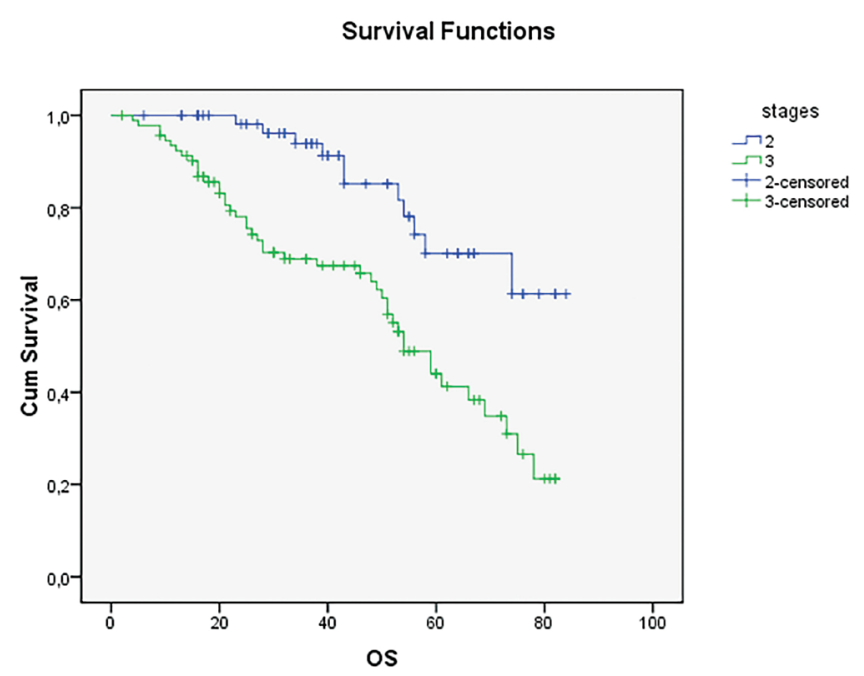

Figure 1. OS, according to stage II and stage III (Log-rank $p<0.001)$

OS: Overall survival 
Table 2. General characteristics of the patients according to neutrophil-lymphocyte ratio and platelet-lymphocyte ratio

\begin{tabular}{|c|c|c|c|c|c|c|}
\hline & NLR $<3.6$ & NLR $\geq 3.6$ & $p$ & PLR $\geq 192$ & PLR $\geq 192$ & $p$ \\
\hline \multicolumn{7}{|l|}{ Age } \\
\hline$<65$ & 52 & 41 & 0.879 & 47 & 46 & 0.314 \\
\hline \multicolumn{7}{|l|}{ Gender } \\
\hline Female & 42 & 29 & 0.527 & 37 & 34 & 0.691 \\
\hline Adenocancer & 71 & 48 & 0.142 & 68 & 51 & 0.139 \\
\hline Others & 17 & 20 & - & 16 & 21 & \\
\hline \multicolumn{7}{|l|}{ LVI } \\
\hline Absent & 56 & 24 & $<0.001$ & 53 & 27 & 0.001 \\
\hline Present & 24 & 37 & - & 21 & 40 & - \\
\hline \multicolumn{7}{|c|}{ Surgical resection } \\
\hline R1 & 7 & 16 & 0.007 & 9 & 14 & 0.125 \\
\hline R0 & 81 & 52 & - & 75 & 58 & - \\
\hline \multicolumn{7}{|l|}{ T stage } \\
\hline $2-3$ & 73 & 50 & 0.153 & 70 & 53 & 0.138 \\
\hline 4 & 15 & 18 & - & 14 & 19 & - \\
\hline \multicolumn{7}{|l|}{ N stage } \\
\hline 0 & 47 & 19 & - & 48 & 18 & - \\
\hline Present & 16 & 46 & - & 16 & 46 & - \\
\hline
\end{tabular}

In the analysis of 1,437 patients who underwent curative surgery and were diagnosed with stage II-III colorectal cancer, LVI and PNI were found to be independent prognostic factors affecting OS (19). In a recent study investigating the importance of perineural and lymphovascular invasion in locally advanced rectal cancer, PNI was determined as the independent prognostic factor that presented the OS compared to LVI (20). In the univariate analysis in this study, LVI and PNI were found to be statistically significant, but were not prognostic.

In a study with 508 patients undergoing radical surgery, degree of differentiation, age, T stage, nodal involvement, PNI were identified as independent prognostic factors affecting OS (21). Nodal involvement and advanced $\mathrm{T}$ stage were independent prognostic factors negatively affecting the OS, as in our study.

The TNM staging system directs us the clinicians to choose the appropriate treatment for the patient and is standard. According to the
American Joint Committee of Cancer-7 rectal cancer staging system, a minimum of 12 lymph nodes are required for the suitable tumour stage and is involved with a good OS in patients treated with surgery (22). In our study, less than 12 lymph nodes were removed in 18\% of the patients, which did not affect the OS. In another study, NLR and PLR both demonstrated their potential significance for the TNM stage assessment in CRC patients (23). The increase in NLR was also related to the TNM stages in our study.

A study evaluating 205 surgical CRC patients concluded that preoperative high NLR is an independent prognostic marker for OS and cancerspecific survival (24). In a retrospective evaluation of 300 patients and in another study with 200 patients who underwent curative resection for CRC, NLR and PLR were found as independent prognostic factors that negatively impacted the OS $(25,26)$. In our study, only NLR was an independent prognostic factor. 
Table 3. Univariate and multivariate analysis for overall survival

\begin{tabular}{|c|c|c|c|c|c|c|}
\hline & \multicolumn{3}{|c|}{ Univariate } & \multicolumn{3}{|c|}{ Multivariate } \\
\hline & HR & $\% 95 \mathrm{Cl}$ & p & HR & $\% 95 \mathrm{Cl}$ & $p$ \\
\hline \multicolumn{7}{|l|}{ Age } \\
\hline$\geq 65$ & 0.924 & $0.537-1.591$ & 0.776 & - & - & $\mathrm{NI}$ \\
\hline \multicolumn{7}{|l|}{ Gender } \\
\hline \multicolumn{7}{|l|}{ Histology } \\
\hline Adenocancer & - & 1 & - & - & 1 & - \\
\hline Others & 0.514 & $0.288-0.919$ & 0.025 & 0.546 & $0.279-1.068$ & 0.077 \\
\hline \multicolumn{7}{|l|}{ LVI } \\
\hline Absent & - & 1 & - & - & 1 & - \\
\hline Present & 0.243 & $0.137-0.430$ & $<0.001$ & 0.721 & $0.356-1.458$ & 0.362 \\
\hline \multicolumn{7}{|c|}{ Surgical resection } \\
\hline R0 & - & 1 & - & - & 1 & - \\
\hline R1 & 0.264 & $0.141-0.495$ & $<0.001$ & 0.341 & $0.157-0.740$ & 0.007 \\
\hline \multicolumn{7}{|l|}{ T stage } \\
\hline $\mathrm{T} 2-3$ & - & 1 & - & - & 1 & - \\
\hline T4 & 0.370 & $0.206-0.663$ & 0.001 & 0.261 & $0.129-0.527$ & $<0.001$ \\
\hline \multicolumn{7}{|l|}{$\mathrm{N}$ stage } \\
\hline III & 0.367 & 0.193-0.699 & 0.002 & 0.098 & $0.013-0.710$ & 0.022 \\
\hline \multicolumn{7}{|l|}{ Metastases } \\
\hline Absent & - & 1 & - & - & 1 & - \\
\hline Present & 0.089 & $0.044-0.183$ & $<0.001$ & 0.130 & 0.054-0.309 & $<0.001$ \\
\hline \multicolumn{7}{|l|}{ NLR } \\
\hline$N L R<3.6$ & - & 1 & - & - & 1 & - \\
\hline$N L R \geq 3.6$ & 0.180 & $0.096-0.338$ & $<0.001$ & 0.378 & $0.154-0.930$ & 0.034 \\
\hline \multicolumn{7}{|l|}{ PLR } \\
\hline PLR $<192$ & - & 1 & - & - & 1 & - \\
\hline PLR $\geq 192$ & 0.183 & $0.096-0.349$ & $<0.001$ & 0.509 & $0.218-1.188$ & 0.118 \\
\hline
\end{tabular}

In many studies, inflammatory responses have been evaluated with haematological markers. In colorectal cancer, lymphocytes play a significant role in the immune response. Cellular immunity decreases in the presence of systemic inflammation. This promotes a decrease in CD4 lymphocytes and an increase in CD8 suppressor T lymphocytes. Lymphocytes commonly play a considerable role in the growth and progression of cancer via regulation of cell-mediated immunity. Myeloid growth factors are produced by tumours, which may increase the number of neutrophilic granulocytes at the site of the tumour (26). Platelets are taken into the tumour microenvironment and release platelet-induced growth factor and transformative growth factor to enable tumour growth. It regulates angiogenesis and protects tumour 
cells from host immune surveillance and direct cellular contact with natural killer cells by forming a network with fibrin surrounding tumour cells during haematogenous propagation (27). Tumour cells can manipulate platelet activity to optimise tumour growth, proliferation, survival and metastasis.

The retrospective character of our study, the frequent use of neoadjuvant chemo RT in patients with rectal cancer nowadays and the small number of patients constitutes our limitations.

\section{Conclusion}

In our study, due to its low cost, extensive use and association with OS, NLR was found to be a better prognostic marker. Besides, R1 resection, T4 stage, lymph node positivity, presence of metastases, TNM stage III were found to be prognostic factors that negatively affect OS. NLR is a biomarker that is thought to be an indicator of the systemic inflammatory response and can be easily obtained as a prognostic biomarker candidate.

\section{Ethics}

Ethics Committee Approval: This study was approved by University Health Sciences Turkey, İstanbul Training and Research Hospital's Ethics Committee (decision no: 2244/ date: 27.04.2020).

Informed Consent: Due to the retrospective design of the study, informed consent was not obtained from the patients.

Peer-review: Externally and internally peer-reviewed.

Authorship Contributions: Surgical and Medical Practices - D.C.T., A.H.Y., E.A.; Concept - Ö.M., B.İ., A.H.Y., E.A.; Design - Ö.M., N.D., A.H.Y.; Data Collection or Processing - Ö.M., B.İ., D.C.T., E.A.; Analysis or Interpretation - Ö.M., B.İ., N.D.; Literature Search - Ö.M., N.D., D.C.T.; Writing - Ö.M.

Conflict of Interest: No conflict of interest was declared by the authors.

Financial Disclosure: The authors declared that this study received no financial support.

\section{References}

1. Bray F, Ferlay J, Soerjomataram I, Siegel RL, Torre LA, Jemal A. Global cancer statistics 2018: GLOBOCAN estimates of incidence and mortality worldwide for 36 cancers in 185 countries. CA Cancer J Clin 2018; 68: 394-424.

2. West NR, McCuaig S, Franchini F, Powrie F. Emerging cytokine networks in colorectal cancer. Nat Rev Immunol 2015; 15: 615-29.

3. Shalapour S, Karin M. Immunity, inflammation, and cancer: an eternal fight between good and evil. J Clin Invest 2015; 125: 3347-55.

4. Mallappa S, Sinha A, Gupta S, Chadwick SJ. Preoperative neutrophil to lymphocyte ratio $>5$ is a prognostic factor forrecurrent colorectal cancer. Colorectal Dis 2013; 15: 323-8.

5. Azab B, Shah N, Radbel J, Tan P, Bhatt V, Vonfrolio S, et al. Pretreatment neutrophil/lymphocyte ratio is superior to platelet/lymphocyte ratio as a predictor of long-term mortality in breast cancer patients. Med Oncol 2013; 30: 432.

6. Goubran HA, Stakiw J, Radosevic M, Burnouf T. Platelet-cancer interactions. Semin Thromb Hemost 2014; 40: 296-305.
7. Goubran HA, Stakiw J, Radosevic M, Burnouf T. Platelets effects on tumor growth. Semin Oncol 2014; 41: 359-69.

8. Maeda K, Shibutani M, Otani H, Nagahara H, Ikeya T, Iseki Y, et al. Inflammation-based factors and prognosis in patients with colorectal cancer World J Gastrointest Oncol 2015; 7: 111-7.

9. Graziosi L, Marino E, De Angelis V, Rebonato A, Cavazzoni E, Donini A. Prognostic value of preoperative neutrophils to lymphocytes ratio in patients resected for gastric cancer. Am J Surg 2015; 209: 333-7.

10. Sellers CM, Uhlig J, Ludwig JM, Stein SM, Kim HS. Inflammatory markers in intrahepatic cholangiocarcinoma: Effects of advanced liver disease. Cancer Med 2019 ; 8: 5916-29.

11. Liu J, Li S, Zhang S, Liu Y, Ma L, Zhu J, et al. Systemic immune-inflammation index, neutrophil-to-lymphocyte ratio, platelet-to-lymphocyte ratio can predict clinical outcomes in patients with metastatic non-small-cell lung cancer treated with nivolumab. J Clin Lab Anal 2019; 33: e22964.

12. Sagaert $X$, Vanstapel $A$, Verbeek $S$. Tumor heterogeneity in colorectal cancer: what do we know so far? Pathobiology 2018; 85: 72-84.

13. Pinsky PF, Schoen RE. Colorectal cancer incidence by age among patients undergoing surveillance colonoscopy. JAMA Intern Med 2015; 175: 858-60.

14. Murphy G, Devesa SS, Cross AJ, Inskip PD, McGlynn KA, Cook MB. Sex disparities in colorectal cancer incidence by anatomic subsite, race and age. Int J Cancer 2011; 128: 1668-75.

15. Nakagawa H, Ito H, Hosono S, Oze I, Mikami H, Hattori M, et al. Changes in trends in colorectal cancer incidence rate by anatomic site between 1978 and 2004 in Japan. Eur J Cancer Prev 2017; 26: 269-76.

16. Tan Y, Fu J, Li X, Yang J, Jiang M, Ding K, et al. A minor ( $<50 \%)$ signet-ring cell component associated with poor prognosis in colorectal cancer patients: a 26-year retrospective study in China. PLoS One 2015; 10: e0121944.

17. Raab HR. Die R1-Resektion beim Rektumkarzinom [R1 resection in rectal cancer]. Chirurg 2017; 88: 771-6.

18. Sung S, Kim SH, Lee JH, Nam TK, Jeong S, Jang HS, et al. Continuous Effect of Radial Resection Margin on Recurrence and Survival in Rectal Cancer Patients Who Receive Preoperative Chemoradiation and Curative Surgery: A Multicenter Retrospective Analysis. Int J Radiat Oncol Biol Phys 2017; 98: 647-53.

19. Huh JW, Lee JH, Kim HR, Kim YJ. Prognostic significance of lymphovascular or perineural invasion in patients with locally advanced colorectal cancer. Am J Surg 2013; 206: 758-63.

20. Song JH, Yu M, Kang KM, Lee JH, Kim SH, Nam TK, et al. Significance of perineural and lymphovascular invasion in locally advanced rectal cancer treated by preoperative chemoradiotherapy and radical surgery: Can perineural invasion be an indication of adjuvant chemotherapy? Radiother Oncol 2019; 133: 125-31.

21. Long P, Zang Y, Wang H, Liang X, Xie X, Han Z, et al. Prognostic Nomogram for Patients with Radical Surgery for Non-Metastatic Colorectal Cancer Incorporating Hematological Biomarkers and Clinical Characteristics. Onco Targets Ther 2020 ;13: 2093-102.

22. Li Q, Zhuo C, Cai G, Li D, Liang L, Cai S. Increased number of negative lymph nodes is associated with improved cancer specific survival in pathological IIIB and IIIC rectal cancer treated with preoperative radiotherapy. Oncotarget 2014; 5: 12459-71.

23. Jia J, Zheng X, Chen Y, Wang L, Lin L, Ye X, et al. Stage-dependent changes of preoperative neutrophil to lymphocyte ratio and platelet to lymphocyte ratio in colorectal cancer. Tumour Biol 2015; 36: 9319-25.

24. Ying HQ, Deng QW, He BS, Pan YQ, Wang F, Sun HL, et al. The prognostic value of preoperative NLR, d-NLR, PLR and LMR for predicting clinical outcome in surgical colorectal cancer patients. Med Oncol 2014; 31: 305. 
25. Zou Z, Liu H, Ning N, Li S, Du X, Li R. Clinical significance of pre-operative neutrophil lymphocyte ratio and platelet lymphocyte ratio as prognostic factors for patients with colorectal cancer. Oncology Letters 2016; 11: 2241-8.

26. Kwon HC, Kim SH, Oh SY, Lee S, Lee JH, Choi HJ, et al. Clinical significance of preoperative neutrophil-lymphocyte versus platelet-lymphocyte ratio in patients with operable colorectal cancer. Biomarkers 2012; 17: 216-22.
27. Sharma D, Brummel-Ziedins KE, Bouchard BA, Holmes CE. Platelets in tumor progression: A host factor that offers multiple potential targets in the treatment of cancer. J Cell Physiol 2014; 229: 1005-15. 